\title{
Keanekaragaman Koloni Mikroorganisme Rizosfer Lahan Tebu (Saccharum officinarum) Pada Penggunaan Pupuk Bio-Slurry dan Pupuk Kimia
}

\section{Colony Diversity of Rizosphere Microorganisms of Sugarcane (Saccharrum officinarum) Field on Bio-Slurry and Chemical Fertilizers Utilization}

\author{
Adifatul Ismy Nador ${ }^{1 *}$, Ahmad Syauqi ${ }^{2 * *}$, Hasan Zayadi ${ }^{3}$ \\ ${ }^{123}$ Departemen of Biology FMIPA UNISMA, Indonesia
}

\begin{abstract}
ABSTRAK
Keanekaragaman mikroorganisme sangat penting dalam keseimbangan ekosistem tanah juga merupakan indikator kesehatan tanah dan dapat mempengaruhi kondisi tanaman yang tumbuh di atasnya. Rizosfer merupakan bagian tanah yang berada di sekitar perakaran tanaman. Aktivitas beberapa mikroorganisme rizosfer berperan dalam siklus hara dan proses pembentukan tanah, pertumbuhan tanaman, memengaruhi aktivitas mikroorganisme, serta sebagai pengendali hayati terhadap patogen akar. Penelitian ini bertujuan untuk mengetahui nilai indeks keanekaragaman mikroorganisme rizosfer tebu (Saccharum officinarum) yang menggunakan Bio-slurry dan pupuk kimia. Penelitian ini menggunakan metode diskriptif eksploratif. Data yang dianalisis berupa hasil pengukuran $\mathrm{pH}$, jumlah koloni mikroorganisme dan indeks keragaman. Keanekaragaman koloni mikroorganisme rizosfer lahan tebu yang menggunakan Bio-slurry dan yang menggunakan Pupuk kimia tergolong rendah masing-masing bernilai 0,47 dan 0,69. Kelompok koloni mikroorganisme yang ditemukan pada masing-masing lahan yaitu bakteri dan jamur.
\end{abstract}

Kata kunci: Keanekaragaman, Rizosfer, Saccharum officinarum, Bio-slurry, Pupuk Kimia

\begin{abstract}
The diversity of microorganisms is very important in the balance of soil ecosystems is also an indicator of soil health and can affect the condition of plants that grow on it. Rizosphere is a part of the soil around the root of a plant. The activity of some rhizosphere microorganisms plays a role in the nutrient cycle and the process of soil formation, plant growth, affecting microorganism activity, and as biological control of root pathogens. The research objective was to determine the value of the sugarcane (Saccharum officinarum) rhizosphere microorganism index using Bio-slurry and chemical fertilizers. This study uses descriptive explorative methods. The data analyzed in the form of measurement of $\mathrm{pH}$, number of microorganism colonies and diversity index. Diversity of Colonies Rhizosphere microorganisms Sugarcane land that uses Bio-slurry and those using Chemical Fertilizer are classified as low respectively 0.47 and 0.69. Colony groups found in each land are bacteria and fungi.
\end{abstract}

Keywords: Diversity, Rizosphere, Saccharum officinarum, Bio-slurry, Chemical Fertilizers

*) Adifatul Ismy Nador, Jurusan Biologi FMIPA UNISMA. JL. MT. Haryono 193, Malang 65144. Tlp. 085755033149 email: izzmyadiva@gmail.com

**) Ir. Ahmad Syauqi, M.Si, Jurusan Biologi FMIPA UNISMA. JL. MT. Haryono 193, Malang 65144. Tlp. 08986307836 email: ahmadandro.as@gmail.com

Diterima Tanggal 9 Agustus 2017 - Publikasi Tanggal 25 Agustus 2019 


\section{Pendahuluan}

Tanaman tebu adalah tanaman menghasilkan gula yang menjadi salah satu sumber karbohidrat. Seiring dengan pertambahan jumlah penduduk menunjukkan bahwa tanaman tebu kebutuhannya terus meningkat. Namun peningkatan konsumsi gula belum dapat diimbangi oleh produksi gula dalam negeri [1]. Tanaman tebu membutuhkan unsur esensial Makro seperti Nitrogen $(\mathrm{N})$, Fosfor $(\mathrm{P})$, dan Kalium $(\mathrm{K})$ dalam jumlah yang cukup banyak, sedangkan ketersediaan unsur tersebut di dalam tanah sangat terbatas, maka unsur - unsur tersebut perlu ditambahkan melalui pemupukan [2]. Jenis pupuk yang dapat diberikan untuk menambah unsur hara ada dua macam, yaitu pupuk organik dan pupuk anorganik.

Salah satu pupuk organik yang dimanfaatkan untuk menyuburkan tanah pertanian adalah Bioslurry. Bio-slurry berupa hasil dari limbah cair biogas. Limbah cair biogas adalah kotoran ternak yang telah hilang gasnya (slurry), dan sangat kaya akan unsur-unsur yang pastinya sangat dibutuhkan oleh. Pupuk organik dari biogas ini sudah diuji cobakan pada beberapa tanaman diantaranya: jagung, bawang merah, padi, dan tebu [3].

Bio-slurry mengandung nutrisi yang sangat penting untuk pertumbuhan tanaman. Nutrisi makro yang dibutuhkan dalam jumlah yang banyak seperti Nitrogen $(\mathrm{N})$, Phosphor $(\mathrm{P})$, Kalium $(\mathrm{K})$, Kalsium (Ca), Magnesium (Mg), dan Sulfur (S). Serta nutrisi mikro yang hanya diperlukan dalam jumlah sedikit seperti Besi (Fe), Mangan (Mn), Tembaga (Cu), dan Seng ( $\mathrm{Zn}$ ).

Selain memiliki bahan organik yang bernutrisi lengkap, kandungan bio-slurry yang lain adalah mengandung mikroorganisme "pro biotik" yang dapat membantu menyuburkan tanah (memperbaiki sifat fisik, biologi dan kimia tanah), menambah nutrisi, dan mengendalikan patogen pada tanah. Tanah menjadi lebih subur dan sehat sehingga produktivitas tanaman lebih baik. Mikroorganisme yang terkandung di dalam bio-slurry diantaranya: (1) mikroorganisme selulitik untuk pengomposan, (2) mikroba penambat nitrogen untuk menangkap dan menyediakan nitrogen, (3) mikroba pelarut fosfat untuk melarutkan dan menyediakan fosfor yang siap diserap tanaman, dan (4) mikroorganisme Lactobacillus sp untuk mengendalikan serangan penyakit tular tanah.

Keanekaragaman mikroorganisme juga sangat penting dalam keseimbangan ekosistem [4]. juga dapat menentukan indikator tanah itu dikatakan sehat atau tidak dan juga dapat mempengaruhi kondisi tanaman yang tumbuh di atasnya. Mikroorganisme dapat melindungi tanaman dari berbagai penyakit, dengan cara menekan patogen tanah melalui sifat antagonisme mikroorganisme tersebut.

Rizosfer merupakan bagian tanah yang berada di area sekitar perakaran tanaman. Aktivitas mikroorganisme rizosfer ini juga dipengaruhi oleh aktivitas sel akar tanaman. Beberapa mikroorganisme rizosfer berperan dalam siklus hara dan proses pembentukan tanah, pertumbuhan tanaman, juga yang memengaruhi aktivitas mikroorganisme, serta sebagai pengendali hayati terhadap patogen akar [5].

Pada penelitian sebelumnya menjelaskan bahwa Aplikasi plant compost dan vermicompost dapat meningkatkan populasi mikroorganisme pada rizosfer tanaman kedelai varietas JS80-21 dibanding dengan aplikasi pupuk NPK [5]. Penelitian ini dilakukan untuk mengetahui keanekaragaman koloni mikroorganisme rizosfer tebu (Saccharum officinarum) pada penggunaan pupuk bio-slurry dan pupuk kimia.

\section{Material dan Metode}

Alat yang digunakan adalah mikroskop, timbangan analitik, erlenmeyer, camera, pipet tetes, inkubator, cawan petri, gunting, gelas ukur, hot plate, bunsen, autoklaf, alat tulis. Bahan yang digunakan dalam penelitian adalah: sampel tanah dari rizosfer tanaman tebu yang mengandung bioslurry, Sampel tanah dari rizosfer tanaman tebu yang mengandung pupuk kimia, PCA (Plate Conut Agar), Aquades, plastik klip, Kapas, Benang kasur, Kertas sampul.

Penelitian ini menggunakan metode deskriptif eksploratif untuk mendeskripsikan, menggambarkan atau melukislukiskan sesuatu secara sistematis. Keanekaragaman mikroorganisme yang dimaksud adalah keanekaragaman koloni mikroorganisme pada daerah rizosfer. Sampel diambil 
dari tanah rizosfer tebu (Saccharum officinarum. L) yang mengandung Bio-slurry dan yang mengandung pupuk kimia.

Parameter yang diukur merupakan keanekaragaman koloni mikroorganisme menggunakan rumus sebagai berikut:

$$
\mathrm{H}^{\prime}=-\Sigma \mathrm{p} i \ln \mathrm{p} i
$$

dimana: $\mathrm{H}^{\prime}=$ indeks keanekaragaman, $\mathrm{P} i=\mathrm{n} i / \mathrm{N}$ (peluang individu untuk tiap spesies), $\mathrm{n} i=\mathrm{Jumlah}$ individu spesies ke $I, \mathrm{~N}=$ jumlah total individu [6].

Sampel tanah diambil dari beberapa tanaman tebu. Penetapan lokasi sampel di lapangan dilakukan secara acak terpilih. Diambil sampel tanah disekitar $(1-2 \mathrm{~cm})$ akar tanaman tebu dari 10 rumpun tanaman, masing - masing $50 \mathrm{~g}$ tiap rumpun. Kemudian dimasukkan ke dalam plastik klip, Selanjutnya sampel dimasukkan ke wadah yang sudah berisi es batu (box ice) kemudian dibawa ke laboratorium.

Semua alat yang digunakan dicuci terlebih dahulu kemudian dikeringkan. Alat-alat-alat kaca dan plastik seperti cawan petri, pipet tetes, gelas ukur dan lain-lain dibungkus kertas sampul dan diikat dengan rapi. Sedangkan alat-alat yang lain Erlenmeyer dan tabung reaksi, sebelum dibungkus menggunakan kertas sampul,ditambahkan kapas pada mulut alat. Lalu disterilkan dengan autoklaf selama 15 menit dengan temperature $121 \square$.

Pembuatan Media kering PCA seberat 22,5 g kemudian dilarutkan dengan $1000 \mathrm{ml}$ aquades steril. medium tersebut dimasukkan ke dalam Erlenmeyer, lalu dipanaskan sambil diaduk diatas hot plate sampai larutan homogeny dan mendidih. Disiapkan cawan petri lalu dituangkan kira - kira 15 ml, kemudian cawan ditutup. Lalu disterilkan dengan autoklaf selama 15 menit dengan temperature $121{ }^{\circ} \mathrm{C}$.

Pengenceran sampel merupakan awal kegiatan yang dilakukan sebelum penanaman mikroorganisme. Pengenceran dilakukan untuk memperoleh biakan murni baik menggunakan media cair maupun padat. Adapun Prinsip pengenceran adalah menurunkan jumlah mikroorganisme sehingga suatu saat ditemukan satu sel dalam tabung reaksi. Sampel yang telah diencerkan disebar pada media tertentu. Mikroorganisme yang di tanam pada media dapat menyebar luas ke seluruh media sehingga perhitungan jumlah koloni dapat dilakukan dengan mudah [7].

Sampel tanah rizosfer tebu diambil $10 \mathrm{~g}$ kemudian dilarutkan $100 \mathrm{~mL}$ aquades kemudian digoyangkan hinggan homogen. Disiapkan $9 \mathrm{ml}$ aquades dalam 4 tabung reaksi yang semuanya steril. Masing - masing tabung reaksi di beri label $10^{-1}$ sampai $10^{-4}$. Diambil $1 \mathrm{~mL}$ kemudian diencerkan dalam tabung reaksi berlabel $10^{-1}$ dan diteruskan hingga $10^{-4}$. Diambil masing - masing $1 \mathrm{~mL}$ dengan pipet steril pada tabung reaksi yang berlabel $10^{-4}$ secara aseptis dan ditanamkan ke dalam medium PCA yang telah disiapkan. Cawan diputar-putar seperti angka 8 (delapan) tanpa mengangkat permukaan meja. Diinkubasi pada suhu ruangan $31^{\circ} \mathrm{C}$ selama $24-48$ jam dan diamati keanekaragaman koloni mikroorganisme yang tumbuh.

Pengamatan dapat dilakukan pada tiap koloni yang tumbuh secara makroskopis meliputi; bentuk,tepi, elevasi, sifat permukaan, pigmentasi, kepekatan, ukuran, dan karakter optik. Pengamatan secara mikroskopis berupa dapat dilihat dari bebrapa bentuk bakteri yaitu bulat (tunggal: coccus, jamak: cocci ), batang atau slinder (tunggal: bacillus, jamak: bacilli).Bentuk bakteri dapat dipengaruh oleh keadaan medium dan usia. Kondisi bakteri harus sama untuk membandingkan bentuk serta ukuran bakteri. Bakteri berukuran kecil sehingga memerlukan mikroskop untuk mengamatinya [7].

\section{Hasil dan Diskusi}

Faktor abiotik yang diobservasi dalam penelitian ini adalah potent Hydrogen $(\mathrm{pH})$ tanah. potent Hydrogen $(\mathrm{pH})$ pada lahan yang mengandung bio-slurry dan lahan yang mengandung pupuk kimia masing - masing adalah 7,1 dan 7,3. Pertumbuhan mikroorganisme tergantung pada $\mathrm{pH}$ karena mempengaruhi aktivitas enzim. Setiap jenis mikroorganisme memiliki kondisi $\mathrm{pH}$ yang berbeda-beda. Bakteri pada umumnya hidup di sekitar ph netral sedangkan jamur dapat hidup dengan baik pada kondisi asam, sehingga Mikroba yang hidup di luar batas tersebut akan mengalami kematian [8]. 
Tanah digunakan sebagai tempat untuk tumbuhnya berbagai jenis tumbuhan dan mikroorganisme. Tanah menyediakan kebutuhan nutrisi seperti bahan organik sebanyak $4-10 \%$. Kegiatan metabolisme masing-masing saling berpengaruh satu sama lainnya dan sebagai habitat menentukan apakah kedua makhluk tersebut dapat bekerja sama dalam bentuk simbiosis atau tidak. Daerah tertentu dalam tanah yang banyak perakaran tanaman akan berpengaruh oleh aktivitas metabolisme sel akar jenis tanaman dan menetukan macam mikroorganisme manakah yang dapat melangsungkan hidupnya [8].

Mikroorganisme di lingkungan dapat ditemukan dalam populasi campuran. Sifat biakan, morfologi, sifat faal dan lain-lain yang akan dipelajari diisolasi berupa biakan murni. Isolasi harus memperhatikan hal penting diantaranya; (1) sifat spesies mikroorganisme yang akan diisolasi; (2) habitat mikroorganisme; (3) media yang sesuai; (4) teknik inokulasi mikroorganisme; (5) teknik inkubasi mikroorganisme; (6) mikroorganisme yang diisolasi adalah biakan murni yang dimaksudm(7) cara memelihara agar mikroorganisme yang diisolasi tetap biakan murni [7].

Perhitungan mikroba dapat dilakukan dengan teknik hitungan secara langsung. Perhitungan jumlah mikroba secara langsung dapat menetukan jumlah mikroba jumlah mikroba secara keseluruhan, baik yang mati maupun yang hidup [7]. Jumlah Koloni mikroorganisme yang didapatkan pada tanah rizosfer yang mengandung bio-slurry sebanyak 5,6 $\times 10^{4}$. Sedangkan jumlah koloni mikroorganisme yang didapatkan pada tanah rizosfer yang mengandung pupuk kimia sebanyak $48 \mathrm{x}$ $10^{4}$, keduanya dibedakan berdasarkan karakter makroskopis dan mikroskopis. Adapun karakter makroskopis dibedakan berdasarkan warna, bentuk dan ukuran. Sedangkan karakter mikroskopis dapat dilihat berdasarkan bentuk sel mikroorganisme.

Pada tanah rizosfer tebu yang mengandung pupuk bio-slurry jika dilihat berdasarkan karakteristik makroskopis dan mikroskopis ditemukan enam macam koloni mikroorganisme, tiga koloni berupa bakteri dan tiga koloni berupa jamur. Bentuk koloni bakteri yang ditemukan memiliki bentuk bulat dan berukuran kecil, warna koloni yang ditemukan yaitu warna putih susu, putih bening dan kuning Jika dilihat secara mikroskopis bentuk koloni bakteri berurutan yaitu, batang, bulat, dan oval. Sedangkan koloni jamur yang diperoleh yaitu berwarna hitam, kecoklatan dan putih.

Pada koloni jamur yang berwarna kecoklatan diperkirakan termasuk kelompok jamur Rizhopus sp jika dilihat berdasarkan morfologi koloni yang berwarna putih kecoklatan, dan permukaan koloni memiliki serabut. Kelompok jamur rizhopus ini termasuk golongan pelapuk selulosa [9]. sehingga jumlah populasinya banyak ditemukan pada lahan yang banyak mengandung pupuk organik, karena pupuk organik memiliki kandungan selulosan yang sangat tinggi.

Pada tanah yang mengandung pupuk kimia jika dilihat secara makroskopis dan mikroskopis ditemukan enam macam koloni mikroorganisme rizosfer tebu, tiga koloni berupa bakteri dan tiga koloni berupa jamur. Bentuk koloni bakteri yang ditemukan memiliki bentuk bulat dan berukuran kecil, warna koloni yang ditemukan yaitu 24 koloni berwarna putih susu, 16 koloni berwarna putih bening dan 1 koloni berwarna kuning Jika dilihat secara mikroskopis bentuk koloni bakteri berurutan yaitu, bantang dan bulat. Sedangkan koloni jamur yang diperoleh yaitu 1 koloni berwarna hitam, 4 koloni berwarna kuning kehijauan dan 2 koloni berwarna putih.

Bakteri yang berwarna putih susu diperkirakan Bacillus sp. Sel berbentuk batang. Bacillus sp merupakan salah satu bakteri yang banyak ditemukan di daerah rhizosfer [10]. Bakteri Bacillus sp. merupakan kelompok bakteri PGPB (Plant Growth Promoting Bacteria) yang memiliki kemampuan dalam menghasilkan fitohormon seperti seperti asam indol asetat, asam giberelin, sitokinin dan etilen, menghasilkan siderofor, pengikat nitrogen, penghasil antibakteri, antipatogen tanaman serta dapat melarutkan fosfat [11]. Bacillus sp. merupakan bakteri pelarut fosfat yang telah banyak diaplikasikan dalam memicu pertumbuhan tanaman. Bakteri ini di dalam tanah dapat melepaskan unsur $\mathrm{P}$ yang terikat menjadi bebas sehingga tersedia untuk kebutuhan tanaman. Fosfat secara mutlak diperlukan tanaman karena berperan dalam menyimpan dan mentransfer energi serta sebagai komponen protein dan asam nukleat [12].

Salah satu koloni jamur yang diperoleh yaitu diperkirakan termasuk kelompok Aspergillus sp jika dilihat sesuai ciri morfologi koloni yaitu: koloni berwarna kuning kehijauan; miselium berbentuk benang halus. Ciri mikroskopis: terdapat konidiofor, sel kaki dan kepala berkonidium terdiri dari 
gelembung, fialid serta kadang-kadang metula dan konidium; fialid dapat dibentuk langsung pada gelembung uniseriat atau metula biseriat; kepala konidium berbentuk kolumner atau radial. Aspergillus adalah cendawan yang pertumbuhan koloninya sangat cepat sehingga mikroba ini paling sering mengkontaminasi.

Rhizobakteri Bacillus sp. memberikan banyak manfaat tidak hanya bagi tanaman melainkan juga dalam bidang lain sehingga menarik untuk dikaji lebih lanjut. Melalui penelitian ini diharapkan dapat menemukan berbagai macam spesies Bacillus sp. Yang dapat dimanfaatkan terutama dalam melarutkan fosfat sehingga dapat berperan untuk pertumbuhan tanaman.

Salah satu koloni jamur yang diperoleh yaitu diperkirakan termasuk kelompok Aspergillus sp dengan ciri morfologi koloni: koloni berwarna hijau kebiruan dengan area kuning sulfur pada permukaannya; miselium berbentuk benang halus. Ciri mikroskopis: terdapat konidiofor, sel kaki dan kepala berkonidium terdiri dari gelembung, fialid serta kadang-kadang metula dan konidium; fialid dapat dibentuk langsung pada gelembung uniseriat atau metula biseriat; kepala konidium berbentuk kolumner atau radial. Aspergillus adalah cendawan yang pertumbuhan koloninya sangat cepat sehingga mikroba ini paling sering mengkontaminasi.

Jika suatu tanaman di area rizosfernya didominasi oleh mikroba yang menguntungkan maka tanaman di atasnya akan memiliki keragaman yang baik. Dan Sebaliknya terjadinya perubahan dominasi komunitas mikroba rizosfir oleh patogen dapat menyebabkan hilangnya tanaman yang tumbuh di atasnya.

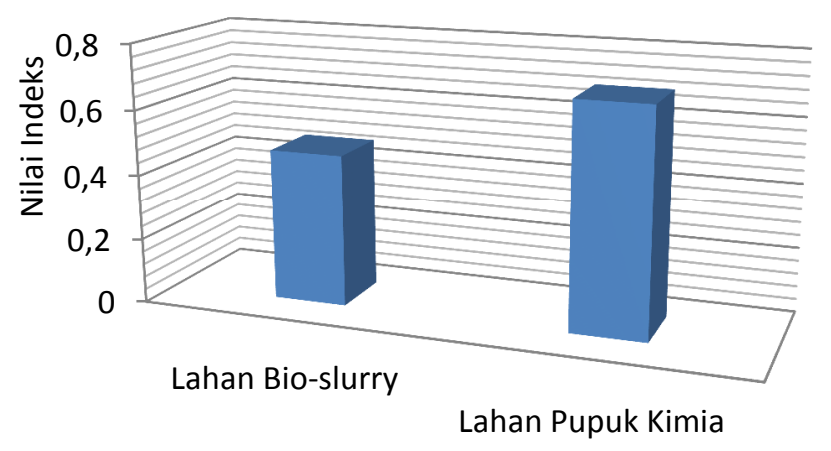

Gambar 1. Histogram Nilai Keanekaragaman pada tiap Lahan Rizosfer Tebu

Nilai keragaman komunitas mikroorganisme rizosfer tebu pada tanah yang mengandung bioslurry adalah 0.47 , sedangkan nilai keragaman komunitas mikroorganisme rizosfer tebu pada tanah yang mengandung pupuk kimia adalah 0,69. Nilai keragaman komunitas mikroorganisme rizosfer tebu pada kedua lahan tergolong rendah. Keragaman mikroorganisme yang rendah dapat dipengaruhi oleh gangguan musiman atau periodik oleh manusia dan alam (Gasango, dkk 2014). Faktor abiotik yang memiliki nilai ph netral juga dapat mempengaruhi pertumbuhan mikroorganisme terutama jamur, karena jamur lebih menyukai $\mathrm{pH}$ yang asam [13].

\section{Kesimpulan}

Koloni mikroorganisme yang ditemukan pada tanah rizosfer tebu yang mengandung bioslurry dan pupuk kimia yaitu koloni bakteri dan jamur. Nilai indeks keragaman koloni mikroorganisme rizosfer tebu yang mengandung bio-slurry dan yang mengandung pupuk kimia masing - masing 0,47 dan 0,69. Nilai keragaman tersebut mengartika bahwa keragaman antara keduanya tergolong rendah. 


\section{Daftar Pustaka}

[1]. Putri A. D., Sudiarso, dan T. Islami. 2013. Pengaruh Komposisi Media Tanam pada Teknik Bud Chip Tiga Varietas Tebu (Saccharum officinarum L). Jurusan Budidaya Pertanian Fakultas Pertanian. Universitas Brawijaya. Malang.

[2]. Purwanti, E. 2008. Pengaruh Dosis Pupuk Majemuk Dan Konsentrasi Em-4 Terhadap Pertumbuhan Bibit Stek Tebu (Saccharum officinarum L). Fakultas Pertanian. Universitas Sebelas Maret. Surakarta.

[3]. Nugroho, P. 2015. Macam - macam Pupuk Organik. Penerbit Pustaka Baru Press. Yogyakarta.

[4]. Fachrul, N.F. 2008. Metode sampling bioekologi. Bumi Aksara. Jakarta (ID).

[5]. Simatupang DS. 2008. Berbagai Mikroorganisme Rhizosfer pada Tanaman Pepaya (Carica papaya L.) di Pusat Kajian Buah-buahan Tropika (PKBT) IPB. Desa Ciomas, Kecamatan Pasirkuda, Kabupaten Bogor, Jawa Barat. [Skripsi]. Institut Pertanian Bogor, Bogor.

[6]. Machludin, A. dan Suwono, H. S. 2011. Jenis dan Komposisi Plankton pada Budidaya Udang Windu, Udang Vename, Ikan Bandeng, dan Rumput Laut di Tambak. Prosiding Forum Inovasi Teknik Akuakultur.http://www. sidik.Litbang.kkp.go.id/idex.php/searchkatalog/downloadDatabyId/17238/773-778 machluddin amin-plankton.pdf. Diakses tanggal 12 juli pukul 12:31 WIB.

[7]. Firmansyah, E. D. 2005. Skripsi. Struktur dan Komposisi Bakteri Limbah Kolam I dan II Pabrik Gula Peasntren Baru Kabupaten Kediri pada Pengelolahan Aerobik. FMIPA UNISMA. Malang:

[8]. Syauqi, A. 2017. Mikrobiologi Lingkungan Peranan Mikroorganisme dalam Kehidupan. ANDUniversitas Islam Malang. Yoyakarta.

[9]. Sutedjo,M.M.,A.G.Kartasapoetra, R. D. S. Sastroatmodjo. 1991. Mikrobiologi Tanah. Penerbit Rineka Cipta, Jakarta.

[11]. Hatmanti A, 2000. Pengenalan Bacillus spp. Oseana Volume XXV(1): 31-41. ISSN 0216-1877. www.oseanografi .lipi.go.id.

[12]. Astuti RP, 2008. Rhizobakteria Bacillus sp. asal tanah rizosfer kedelai yang berpotensi memicu pertumbuhan tanaman. Tesis. Sekolah Pascasarjana IPB. Bogor. Diakses melalui http:// repository.ipb.ac.id/handle/123456789/10708. Pada tanggal 20 Desember 2012.

[13]. Gasango, H. Manu, G. D. dan Tamarampo, J. FWS. 2013. Struktur Komunitas Teripang (Holothuroidea) di Pantai Desa Kakara Pulau Kecamatan Tobelo Kabupaten Tobelo. Jurnal ILMIAH Patax. Vol. 1 (4). ISSN 2302:3589. 